\title{
Pelaksanaan Penjualan Booth Dalam Event World Renewable Energy Congress 2016 Pada PT. Pactoconvex Niagatama
}

\author{
Nurul Vellayeti ${ }^{1}$ dan Maswir ${ }^{2}$ \\ 1,2Jurusan Administrasi Niaga Politeknik Negeri Jakarta \\ Email : ${ }^{1}$ vellayeti@gmail.com, ${ }^{2}$ mawi.maswir@yahoo.co.id
}

\begin{abstract}
Implementation booth selling is the important part of exhibition event, because total selling booth influential of profit and then influential success the event. World Renewable Energy Congress 2016 is a conference event who have exhibition as supporting event and include in Business to business category, a have purpose to enhance company relations in build a business. PT. Pactoconvex Niagatama is organizer who have experience in conference event and exhibition and who have strategy in booth exhibition selling. Somebody selling booth is a sales or salesperson. Purpose in this research is to know selling booth at event World Renewable Energy Congress 2016. Metedology the research is kualitatif with analysis deskriptif deferencial that describes the data obtained in the form of sentence, table, pictures and flowchart.
\end{abstract}

Keywords: Selling booth, Exhibition, Event, Sales Person

\section{Abstrak}

Pelaksanaan penjualan booth merupakan bagian terpenting dalam event pameran, karena jumlah penjualan booth berpengaruh pada profit juga menyangkut sukses atau tidaknya sebuah event. World Renewable Energy Congress 2016 adalah sebuah event konferensi yang memiliki pameran sebagai supporting event dan masuk dalam kategori business to business yang bertujuan untuk menambah relasi perusahaan dalam mengembangkan bisnis. PT. Pactoconvex Niagatama merupakan organizer yang telah berpengalaman dalam menangani event konferensi maupun pameran dan sudah mempunyai alur dalam proses penjualan booth exhibition. Seseorang yang menjual booth disebut sales atau salesperson. Tujuan penelitian ini adalah untuk mengetahui pelaksanaan penjualan booth pada event World Renewable Energy Congress 2016. Metodelogi penelitian adalah kualitatif dengan analisa deskriptif deferensial yaitu menjabarkan data yang diperoleh dalam bentuk kalimat, tabel, gambar dan flowchart.

Kata kunci: Penjualan Booth, Pameran, Event, Salesperson

\section{PENDAHULUAN}

\section{Latar Belakang}

Seiring dengan berkembangnya industri Meeting, Insentif, Conference, Exhibition atau MICE yang sangat pesat beberapa tahun terakhir telah menjadi hal yang membanggakan yang memberi warna baru dalam promosi dan bisnis usaha MICE di
Indonesia. Kegiatan MICE yang paling berkembang adalah pameran. Perkembangan yang begitu ketat juga diikuti dengan persaingan yang begitu ketat pula. Diantaranya disebabkan oleh jumlah pelaku industri pameran yang terus bertambah dan persaingan di antara pameran serupa. Terbukti dari jumlah anggota ASPERAPI 
yang terus bertambah tiap tahunnya sampai tahun 2016 telah berjumlah 850 ribu perusahaan di seluruh Indonesia. Kesuksesan penyelenggaraan pameran menjadi hal yang sangat diharapkan oleh organizer agar mampu bertahan pada persaingan tersebut. Kesuksesan penyelenggaraan pameran diukur dari banyak faktor salah satunya tercapai target penjualan booth.

Berdasarkan fenomena diatas penulis tertarik untuk menaliti proses penjualan booth pada event World Renewable Energy Congress 2016 oleh PT. Pactoconvex Niagatama.

\section{Tinjauan Pustaka}

MICE adalah singkatan dari Meeting, Incentive, Conference, and Exhibition. Sebagaimana disebutkan oleh. Pendit (1999:25), MICE diartikan sebagai wisata konvensi, dengan batasan :Usaha jasa konvensi, perjalanan insentif, dan pameran merupakanusaha dengan kegiatan memberi jasa pelayanan bagi sutaupertemuan kelompok orang (negarawan, usahawan, cendekiawan, dan sebagainya) untuk membahas masalah-masalah yang berkaitan dengan kepentingan bersama. Pada umumnya kegiatan konvensi berkaitan dengan usaha pariwisata lain, seperti transportasi, akomodasi, hiburan (entertainment), perjalanan pra- dan pascakonferensi (pre- and post- conference tours)."

Exhibition berarti pameran, dalam kaitannya dengan industry pariwisata, pameran termasuk dalam bisnis wisata konvensi. Sebagaimana yang disebutkan oleh Kesrul (2004:16), exhibition adalah ajang pertemuan yang dihadiri secara bersama-sama yang diadakan di suatu ruang pertemuan atau ruang pameran hotel, dimana sekelompok Produsen atau pembeli lainnya dalam suatu pameran dengan segmentasi pasar yang berbeda.

Pemasaran merupakan suatu kegiatan penting dalam pameran. Pengertian pemasaran menurut Kotler (2005:10) Pemasaran adalah proses social yang dengan proses itu individu dan kelompok mendapatkan apa yang dibutuhkan dan diinginkan dengan menciptakan penawaran dan secara bebas mempertukarkan produk dan jasa yang bernilai dengan pihak lain.

Pengertian penjualan Menurut Swastha, Basu dan Irawan dalam buku yang berjudul "Manajemen Pemasaran Moderen" tahun 2000 menjelaskan bahwa pengertian penjualan adalah suatu usaha yang terpadu untuk mengembangkan rencana - rencana strategis yang diarahkan dengan tujuan pemuasan kebutuhan dan keiginan pembeli, guna mendapatkan penjualan yang menghasilkan laba. Seseorang yang melakukan kegiatan disebut “salesperson”.

\section{METODE PENELITIAN}

Jenis penelitian yang digunakan dalam penelitian ini adalah study kasus yaitu pengaplikasian penjualan pada Event World Renewable Energy Congress 2016 PT. Pactoconvex Niagatama. Metode Analisa dalam penelitian ini adalah Analisis dekriptif kualitatif yaitu menjabarkan data yang diperoleh dalam bentuk kalimat, tabel, gambar dan flowchart.

\section{HASIL DAN PEMBAHASAN}

World Renewable Energy Congress 2016 (WREC 2016) merupakan forum pertemuan 
para pejabat pemerintah pengambil keputusan dan regulator, politisi dan legislator, ilmuwan, pakar dan akademisi, LSM, eksekutif bisnis, perbankan dan industriawan, pengembang, operator, serta pelaku usaha yang terkait dengan kegiatan usaha energy terbarukan dan efisiensi energi.

Pada event World Renewable Energy Congres 2016 terdapat congress sebagai main event dan exhibition sebagai supporting event. Pada exhibition terdapat perusahaan nasional maupun multinasional yang memamerkan teknologi terbarunya.

Target exhibitor WREC 2016 adalah semua perusahaan dibidang industri energy, mulai dari Peralatan manufaktur, supply produk layanan atau solutions provider. Berikut kategori perusahaannya.

Pelaksanaan Penjualan Booth Exhibitor pada pelaksanaan Event World Renewable Energy Congress 2016 memiliki proses sebagai gambar berikut.

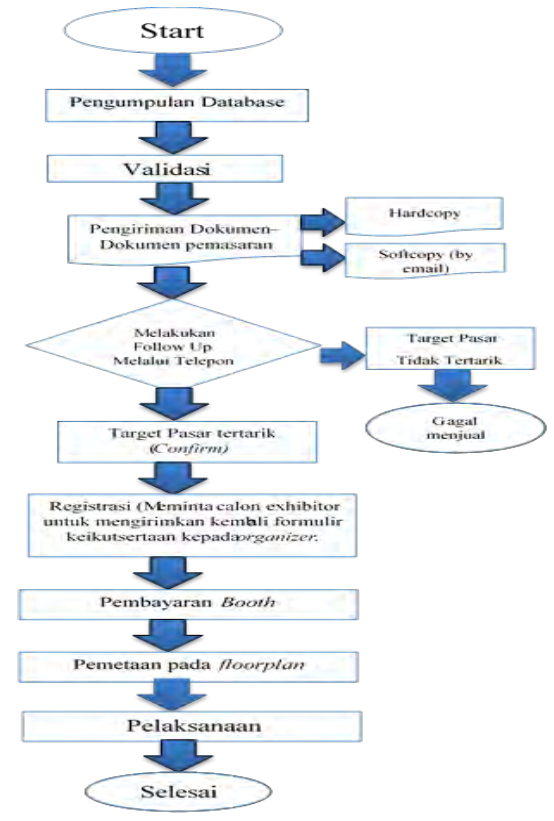

Gambar 1. Proses Penjualan Booth Exhibitor (Sumber: Pacto Convex, Data Diolah, 2016)
1). Pengumpulan Database

Ini adalah tahap awal dimana penulis mengumpulkan dan menyortir database dari perusahaan maupun dari klien.

2). Validasi

Ini adalah tahap kedua yaitu validasi database, database yang s udah dilengkapi dengan mencari data dari internet butuh diuji kembali, apakah data sudah valid ataukan masih banyak kekeliruan. Cara mengujinya yaitu dengan cara menelfon nomor perusahaan.

3) Pengiriman Dokumen Pemasaran

Ada beberapa dokumen yang dikirimkan diantaranya: Announcement World Renewable Energy Congress 2016 , Surat Pengantar dari ketua METI, Iklan WREC 2016, Exhibitor Application Form. Ada dua cara yang dilakukan dalam pengiriman dokumen pemasaran yaitu mengirimkan dokumen hardcopy dan mengirimkan dokumen softcopy..

4) Melakukan Follow Up melalui telpon.

Setelah mengirimkan dokumen langkah selanjutnya adalah memfollow up dokumen yang dikirimkan baik hardcopy maupun softcopy apakah sudah diterima oleh pihak yang terkait, seperti Marketing atau sekertaris perusahaan. Tahap ini juga sebagai penentu apakah perusahaan akan berpartisipasi atau tidak, apabila pihak perusahaan akan berpartisipasi maka akan masuk kedalam tahap berikutnya yaitu registrasi

5) Registrasi

Tahap selanjutnya adalah registrasi, pada tahap ini perusahaan mengembalikan Exhibitor application form. Pada proses ini juga pihak organizer meminta NPWP 
perusahaan yang ditujukan untuk pengecekan faktur pajak, untuk pembuatan invoice.

6) Pembayaran booth

Setelah proses pengembalian invoice oleh organizer, perusahaan exhibitor harus segera melakukan pembayaran dan mengirimkan bukti pembayaran kepada pihak organizer atau divisi sales exhibitor, dengan bukti ini resmi menjadi exhibitor

7) Pemetaan pada Floorplan

Pemetaan pada floorplan didasarkan pada permintaan exhibitor sesuai form registrasi.

8) Pelaksanaan

Pada saat masuknya waktu pameran pekerjaan menjadi tidak terlalu sulit, karena pada waktu pameran sudah tidak banyak tugas yang harus dikerjakan. Tugas penulis saat pelaksanaan adalah stand by di exhibition counter, untuk membantu exhibitor jika ada complain atau tambahan.

Dalam pelaksanaan event WREC 2016 terdapat faktor pendukung dan penghambat yaitu:

1) Faktor pendukung

Sumber daya manusia, Politk dan social, perekonomian nasional, pemerintahan, IT dan sumber daya alam.

2) Faktor Penghambat

Database yang kurang update, calon exhibitor yang lama dalam memberi keputusan dan persaingan pasar.

Tujuan utama dari kegiatan penjualan adalah terjualnya produk dan tercapainya target penjualan produk. Namun seringkali realisasi penjualan tidak memenuhi target penjualan yang telah ditetapkan. Begitu pula dalam kegiatan penjualan booth WREC 2016. Berikut tabel yang berisi target dan pencapaian peserta pameran WREC 2016.

\section{Jumlah Target dan Pencapaian Penjulan Booth WREC 2016}

\begin{tabular}{|c|c|c|}
\hline $\begin{array}{c}\text { Jenis } \\
\text { Booth }\end{array}$ & $\begin{array}{c}\text { Target } \\
\text { Penjualan }\end{array}$ & $\begin{array}{c}\text { Realisasi } \\
\text { Penjualan }\end{array}$ \\
\hline Yellow & 14 booth & 10 booth \\
\hline Pink & 17 booth & 12 booth \\
\hline White & 18 booth & 10 booth \\
\hline Green & 8 booth & - \\
\hline
\end{tabular}

Sumber: Pacto Convex, data diolah, 2016

\section{KESIMPULAN DAN SARAN}

\section{Kesimpulan}

Pada penulisan laporan ini, dan setelah penulis melakukan praktik kerja, penulis menarik beberapa kasimpulan diantaranya:

1. Pameran WREC 2016 ini merupakan jenis order event dimana pihak Masyarakat Energi Terbarukan Indonesia (METI) melakukan permintaan untuk bekerjasama dalam pembuatan pameran dengan PT Pacto Convex.

2. Perusahaan dalam penjualan booth telah menggunakan prosedur yang berlaku sebagaimana dalam analisis diatas, sehingga event berjalan dengan lancar, dan menurut penulis hal ini perlu dipertahankan dan ditingkatkan.

3. Perusahaan sudah melaksanakan penjualan booth secara cukup berhasil, hal ini dikarnakan terdapat faktor pendukung antara lain SDM, social, politik, pemerintahan, IT, dan SDA, Namun ada faktor penghambat antara lain kurang updatenya database, lamanya perusahaan calon exhibitor dalam pengambilan keputusan, dan persaingan pasar. 


\section{Saran}

1. Setelah diteliti dan disurvei prosedur penjualan booth sudah cukup baik, masukan dari penulis untuk dibuat buku pedoman agar karyawan dapan menjadikan acuan dalam proses penjualan booth.

2. meng-cleaning database, yaitu mengecek kembali database yang sudah ada dengan bertanya kepada perusahaan, apakah nomor telepon dan alamat sudah jelas atau belum, cleaning database dilakukan melalui telepon.

3. Lamanya pengambilan keputusan perusahaan calon exhibitor dapat disiasatkan dengan memberikan discount dalam batas waktu yang ditentukan, contoh: discount early bird.

4. Adanya persaingan pasar ini dapat disiasati dengan lebih research kembali tanggal dan lebih mengkategorikan target pasar agar semakin jelas.

\section{DAFTAR PUSAKA}

Basu Swastha dan Irawan, (2005), Manajemen Pemasaran Modern. Liberty, Yogyakarta

Evalina, Lidia, 2005, Event Organizer Pameran, Jakarta: PT. Indeks Kelompok Gramedia.

H. Hoyle, Leonard.2006. Event Marketing. Jakarta: PPM

Kesrul. M.2004. Meeting, Incentive Trip, Conference, Exhibition. Yogyakarta: Graha Ilmu.

Kotler, Philip, 2008. Marketing Management, Jakarta: Erlangga

Noor, Any. 2007. Globalisasi Industri MICE. Bandung: Alfaceta.
Pendit, N.S. 1999, Ilmu Pariwisata, sebuah Pengantar Perdana, Jakarta: Gaya Media.

S, Nyoman Pendit. 2005. Glosary Pariwisata Konteporer, Jakarta: PT Pradnya Paramita.

Wahyuningsih, Sri, 2014, MICE (Meeting, Incentive, Convention, and Exhibition), Medura. International congress and convention association, 2013, Definition of "MICE". (http://www.iccaworld.com/aeps/aeit em.cfm?aeid=29. Diakses 06 November 2016)

Setiawan, Ebta. 2015. Kamus Besar Bahasa Indonesia Daring (Dalam Jaringan / Online). Versi 1.5 (http://kbbi.web.id/. Diakses 06 Nomeber 2016).

Http://www.pacto-convex.com/ (diakses pada tanggal 2 Desember 2016)

Http://www.wrec2016indonesia.com

(diakses pada tanggal 3 Desember 2016)

Http://www.Scribd.com/doc/19793770/MI

CE (diakses pada tanggal 30 November 2016)

Akbar, Djuni dkk. 2011. Proses Penjualan Paket Sponsorship Penyelenggaraan Event Pemilihan Putri Indonesia 2010 dan Jakarta International Java Rockin'Land Festival 2010. Depok: index

\section{Sumber lain}

Keputusan Menteri Pariwisata, Pos, dan Komunikasi Republik Indonesia Nomor

KM.108/HM.703/MPPT-91. 
Nurul Vellayeti dan Maswir

Pelaksanaan Penjualan Booth... 